UDC 621.391

\title{
DEPENDENCE APPROXIMATION OF THE HURST COEFFICIENT ON THE TRAFFIC DISTRIBUTION PARAMETER
}

\author{
Lozhkovskyi A.G., Levenberg Ye.V. \\ O.S. Popov Odessa national academy of telecommunications, Odessa, Ukraine
}

Background. Despite the popularity of the model of self-similar traffic, until now a number of tasks of assessing the quality of service in the packet communication network remains unresolved. Because of the lack of a rigorous theoretical base that can complement the classical queuing theory when designing a packet-based communication network with self-similar traffic, there is no reliable and recognized methodology for calculating parameters and quality indicators for information distribution systems under conditions of the self-similarity effect.

Objective. The aim of the paper is the improvement of the accuracy of calculating the quality of service characteristics by obtaining a new formula for calculating the traffic self-similarity coefficient, depending on the parameter of the form of the Weibull or Pareto distributions. Self-similar traffic or the time interval between stream packets is described by these distributions.

Methods. To calculate the QoS characteristics, you only need to know the parameter $a$ of the Weibull or Pareto distribution form and there is no need to calculate in a rather complicated way, for example, the R/S-method, the self-similarity coefficient of Hurst for traffic.

Results. A significant difference between the real and the linear dependence of the self-similarity coefficient $H$ on the parameter $a$ of the Weibull distribution form or on the parameter $a$ of the Pareto distribution form is detected.

Conclusions. The use of real functional dependences of $H$ on $a$ allows enhancing the accuracy of calculating the quality of service characteristics.

Keywords: quality of service: Hurst coefficient: self-similar traffic.

\section{Introduction}

In packet communication networks, the input information streams can have a constant, variable and mixed bit rate, and therefore the mathematical model of the flow varies from the simplest Poisson to the most complicated model of fractal processes (self-similar traffic).

Although model of self-similar traffic is recognized, until now a number of tasks of assessing the quality of service in the packet network remains unresolved. Because of the lack of a rigorous theoretical base that can complement the classical queuing theory when designing a packet-based communication network with self-similar traffic, there is no reliable and recognized methodology for calculating parameters and quality indicators for information distribution systems under self-similarity conditions. It has been shown in $[1,2]$ that, in the presence of self-similarity properties in the incoming packet stream, with increasing load intensity $\rho$, the service quality characteristics deteriorate, but not as much as is assumed by the Norros method [3]. The discrepancy between the results of modeling and estimates obtained by the Norros method is sometimes hundreds of percent [1]. Obviously, Norros's estimate is significantly overestimated, which requires finding a more accurate solution.
To simulate a process of fractal character, it is necessary to generate random realizations of the fractal Brownian motion fBM. Mathematical modeling of traffic with the effect of fractal Brownian motion uses probability distributions, called "long tail distributions", to which the Weibull and Pareto distributions refer [5].

In multiservice packet communication networks based on packet switching technology, the traffic or the distribution of the number of packets per time unit is well described by a self-similar random process with a self-similar coefficient (Hurst parameter) of $0.65-0.8$ or more [1]. The main reason for the self-similarity of traffic is the integral nature of the network (multiservice). This network is used simultaneously for the transmission of speech, video and data, represented in the form of standard packages. Here, the flow of different applications and services is provided by the same network with unified protocols and control laws. In all the known flow models it was assumed that the probability of the appearance of the next event depends only on the time elapsed since the previous event was made and does not depend on the entire history of events. Thus, traffic models in packet communication networks differ from traditional models. The use of inadequate mathematical models of traffic leads to an incorrect evaluation of the quality of service (QoS) characteristics of the network. 
An adequate model of flows in such networks is selfsimilarity processes, where the input stream is described by a fractal Brownian motion (fBM model). When generating self-similar traffic, the criterion for its selfsimilarity is the so-called long-range dependence. To detect this dependence, the definition of the correlation function is used. For a self-similar process, the correlation properties of the process averaged over different time intervals remain unchanged.

\section{Estimates obtained by the Norros method}

To calculate a single-server system with an infinite queue and a constant service time (fBM/D/1/ $\infty$ model), a solution is known in the form of the Norros formula [3, 4], using the self-similar coefficient $H$, called the Hurst coefficient:

$$
N=(1-\rho)^{H /(H-1)} / \rho^{0.5 /(H-1)} .
$$

Here $N$ is the average number of packets in the system, which can't be exceeded, i.e. this is the upper bound for this number of requirements in the system.

The Hurst method allows to reveal in its packet data statistics such properties as clustering, the tendency to follow the direction of the trend (persistence) and the rapid intermittence of successive values of traffic intensity (bursts of intensity), strong aftereffect, strong memory, self-similarity, the presence of periodic and non-periodic cycles (due to the peculiarities of the transmission protocols used) [5].

The simulation results shown in Fig. 1 show that self-similar traffic with increasing load intensity $\rho$ deteriorates the quality of service characteristics $(N)$, but not as much as is established by the Norros formula. The discrepancy between the simulation results (shown by the "+" sign) and the estimates obtained by the formula (1) (shown by a dashed line) can reach hundreds of percent. Estimation of Norros is greatly overestimated and a more precise solution is needed.

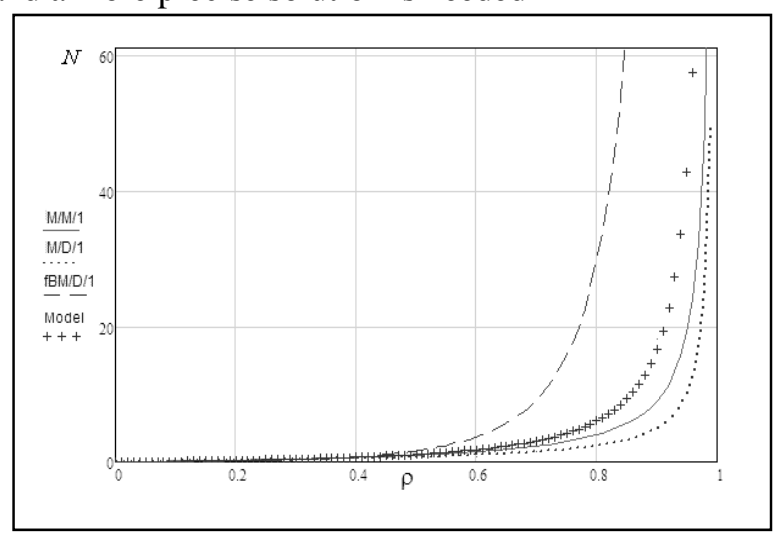

Fig. 1. Modeling $N$ in the $\mathrm{fBM} / \mathrm{D} / 1 / \infty$ model at $H=0,7$

\section{Approximation of traffic by Weibull distribution}

To achieve the self-similarity effect, Pareto or Weibull distributions, often called "long tail distributions", are used. The presence of the "long tail" distribution provides the property of traffic packet, since the probabilities of long intervals between events increase in the distribution (for example, the absence of packets in some interval), and the probabilities of very short intervals also increase to compensate them or concentration of the packets (increase) on another time intervals.

The density of the Weibull distribution is given by the function:

$$
f(x)=\lambda_{0} a x^{a-1} e^{-\lambda_{0} x^{a}},
$$

where $a$-is the shape parameter; $\lambda_{0}-$ is the scale factor.

In practical modeling of self-similar traffic, for example, using the algorithm [6], the Weibull distribution is obtained by switching from a uniform distribution by the inverse function method:

$$
Z_{i}=\left(-\frac{1}{\lambda_{0}} \ln U_{i}\right)^{1 / a},
$$

where $Z_{i}$ - is the $i$-th interval between flow requests; $U-$ is a random number uniformly distributed on the interval $0 \ldots 1$. To ensure the self-similar properties of simulated traffic, it is necessary to set the value of the shape parameter $a$ within the range from 1 to 0 , which should provide the values of the Hurst self-similar coefficient in the range $H=0,5 \ldots 1$, respectively.

The shape parameter $a$ of the Weibull distribution and the Hurst coefficient $H$ are assumed in the following dependence [4]:

$$
H=(2-a) / 2 .
$$

For processes without self-similarity properties, the Hurst parameter is $H<0.5$, and for self-similar processes this parameter is in the range $0.5 \ldots 1$ (the process has a long memory).

The simulation results presented in Fig. 2 show that for the Weibull distribution there is no linear dependence (3) of the coefficient $H$ on the shape parameter of the distribution $a$.

Fig. 2 shows that the real Hurst coefficient HR (dotted curve) depends on the $a$ shape parameter of the Weibull distribution not linearly (solid line), but according to a law close to the exponential one. 


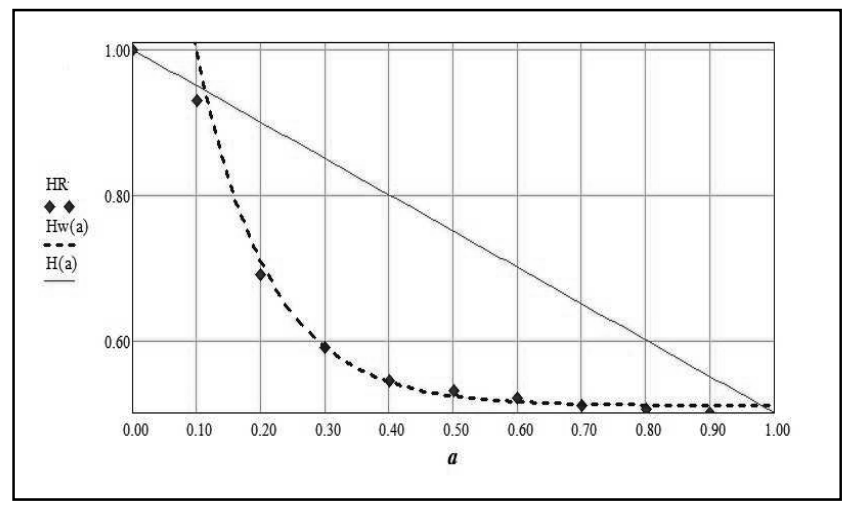

Fig. 2. The dependence of $H$ on $a$ for the Weibull distribution for $H=0,5 \ldots 1,0$

If the actual traffic statistics (the interval of time between requests or packets) is approximated by the Weibull distribution, then for the Norros formula (1) it is necessary to calculate the self-similarity coefficient of Hurst not according to formula (4), but from the formula of the HR approximating curve shown in Fig. 2 by the dotted line. In this case, the accuracy of calculation (1) increases significantly, since, for example, it follows from (4) that for $a=0,3$ the coefficient $H=0,85$, and in fact $H=0,6$, which is $40 \%$ less.

According to the results of simulation [6], the following formula is proposed to calculate the Hurst coefficient of traffic described by the Weibull distribution:

$$
H w=1,2 e^{-9 a}+0,51 \text {. }
$$

The approximation (5) of the Hurst coefficient HR (dashed line), shown in Fig. 2, although not completely corresponds to the curve of the real change in the Hurst coefficient as a function of the parameter a of the Weibull distribution form, but ensures the accuracy of calculating the quality of service characteristics by an order of magnitude higher than calculations using formula (4). At the same time, the calculation error on the average does not exceed $10 \ldots 20 \%$.

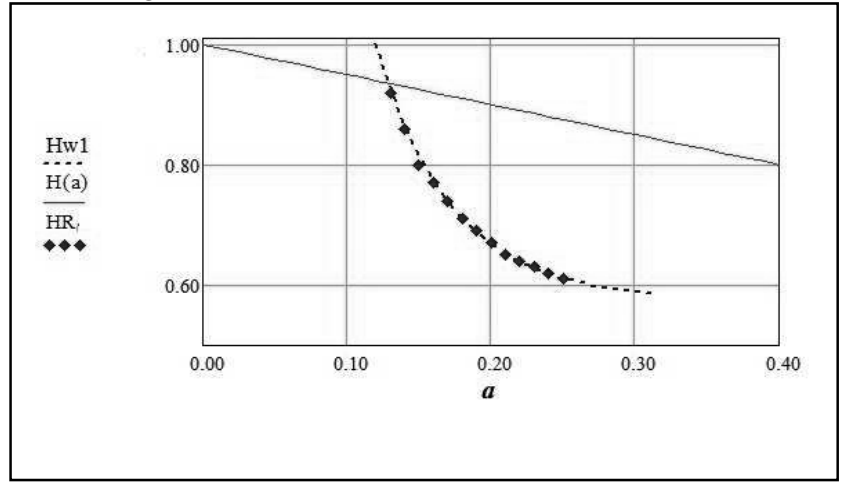

Fig. 3. The dependence of $H$ on $a$ for the Weibull distribution for $H=0,6 \ldots 0,9$
For a range of values of the coefficient $H=0,6 \ldots$ 0,9 , such an approximation is given:

$$
H w=4,1 e^{-19 a}+0,57,
$$

which provides an even more accurate calculation of the Hurst coefficient $H$ as a function of the shape parameter a of the Weibull distribution. It is in this range that the values of the coefficients $H$ of real self-similar packet network traffic are found.

\section{Approximation of traffic by Pareto distribution}

The density of the Pareto distribution is function:

$$
f(\mathrm{x})=\frac{a}{b}\left(\frac{b}{x}\right)^{a+1},
$$

where $a-$ is the shape parameter, which is varied for simulating self-similar traffic in the range from 1 to $2 ; b$ - is the minimum value of the random variable $x$. For $a$ $\leq 2$, the dispersion of the distribution is infinite (which is required as the conditions for self-similarity).

In generation of a random value of the time interval between events in Pareto distribution (7), it is necessary to perform a transition from uniform distribution by the inverse function method [2]:

$$
Z_{i}=\frac{b}{\sqrt[a]{U_{i}}}
$$

where $Z i-$ is the $i$-th interval between events; $U-$ is a random number uniformly distributed on the $0 \ldots 1$.

The shape parameter of the Pareto distribution $a$ and the Hurst coefficient $H$ are assumed in such a relationship [4]:

$$
H=(3-a) / 2 .
$$

To ensure the self-similar properties of the traffic, the values of the shape parameter a should be set in the range from 2 to 1, which provides values for the Hurst coefficient in the range $\mathrm{H}=0,5 \ldots 1$, respectively.

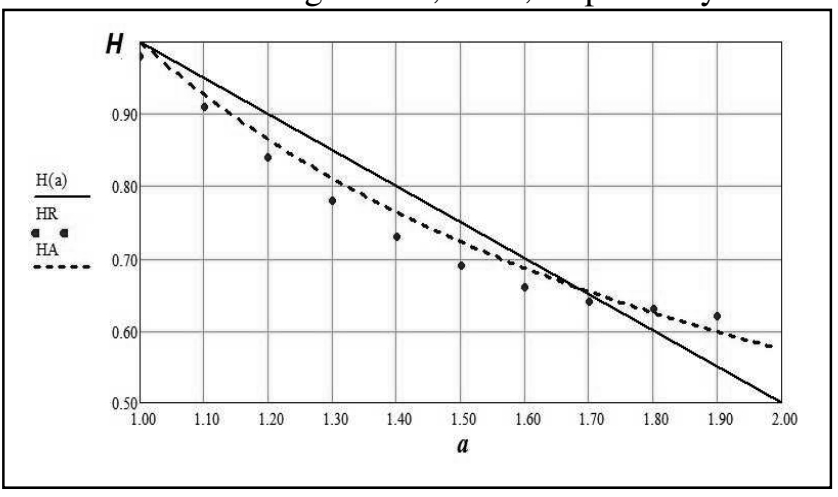

Fig. 4. The dependence of $H$ on $a$ for the Pareto distribution 
The simulation results presented in Fig. 4 show that for the Pareto distribution there is no linear dependence (9) of the coefficient $H$ on the shape parameter of the distribution $a$.

Fig. 4 shows that the real Hurst coefficient HR (dotted curve) depends on the shape parameter $a$ of the Pareto distribution is not linear (solid line), but according to a law close to the exponential one.

Thus, if the real traffic statistics (the time interval between packets) is approximated by the Pareto distribution, then to calculate the quality of service characteristics by the Norros formula (1), the selfsimilarity coefficient of Hurst should not be calculated by formula (9), but by the formula of the HR approximating curve shown in Fig. 3 (dashed line). In this case, the accuracy of the calculation increases by an order of magnitude, while the error does not exceed 10 ... $20 \%$.

According to the results of simulation using the algorithm [6], a very simple formula is proposed for calculating the Hurst coefficient of traffic described by the Pareto distribution:

$$
H p=a^{-0,78},
$$

where $a$-is a shape parameter of the Pareto distribution.

The approximation (10) of the Hurst coefficient HA (dashed line) does not fully correspond to the curve of the real change in the Hurst coefficient as a function of the shape parameter of the Pareto distribution a, but even in this form provides an accuracy of the calculation of the quality of service characteristics by an order of magnitude higher than in calculations with Using formula (9). At the same time, the calculation error on the average does not exceed 10 ... 50\%.

By formula (1) and approximation (10), through the shape parameter of the Pareto distribution $a$, we can calculate, for example, the average number of packets in the system $N$ :

$$
N=(1-\rho)^{\left(\frac{a^{-0,78}}{a^{-0,78}-1}\right) / \rho^{\left(\frac{0,5}{a^{-0,78}-1}\right)} .}
$$

Taking into account the approximations (5) and (10) given, when estimating the quality of service characteristics, it is sufficient to calculate only one of the characteristics, for example, the average number of packets in the system $N$ according to the formula (1) through the shape parameter of the Weibull or Pareto distribution $a$. All remaining characteristics of QoS are calculated using the following formulae, since characteristics such as the average number of packets in the queue $Q$, the average time of packets in the system $T$, and the average number of packets in the queue $W$ are related to $N$ known functional relationships:

$Q=N-\rho-$ average number of packets in the queue.

$T=N / \rho-$ average time of packets in the system,

$W=T-1-$ average time of packets in the system.

\section{Conclusions}

In conclusion, it should be noted that this method allows us to calculate quality of service characteristics (QoS) of self-similar traffic described by Weibull or Pareto distributions in a single-channel $\mathrm{fBM} / \mathrm{D} / 1 / \infty$ system with discrete time of service of packets is much simpler. This simplicity is explained by the fact that for calculation it is necessary to know only the shape parameter a of the Weibull or Pareto distribution and there is no need to calculate the self-similarity coefficient of Hurst for traffic in a rather complicated and laborious way (for example, using the R/S-statistics method). All the graphs presented show a significant difference between the real (5) and the currently used linear dependence (4) of the self-similarity coefficient $H$ on the shape parameter $a$ of the Weibull distribution or the difference between the real (10) and the linear dependence (9) of the self-similarity coefficient $H$ on the shape parameter of the Pareto distribution $a$ in the system $\mathrm{fBM} / \mathrm{D} / 1 / \infty$. Using real functional dependencies of $H$ and $a$ allows enhancing the accuracy of calculating the quality of service characteristics.

\section{References}

[1] Lozhkovskyi A.G. Comparative analysis of methods for calculating quality of service characteristics for self-similar flows in a network / A.G. Lozhkovskyi // Modeling and Information Technology: Collection of scientific works of the IPME them. G. E. Puhov NAS of Ukraine. K., 2008. - No. 47. - P. 187-193. [in Russian].

[2] Lozhkovskyi A.G. Mathematical model of packet traffic. / A.G. Lozhkovskyi, O.V. Verbanov, V.A. Kaptur, V.M. Kolchar // Bulletin of the National Polytechnic University "KhPI". - 2011. - No. 9. - P. 113-119. [in Russian].

[3] Norros Ilkka. A storage model with self-similar input. - Queuing Systems, 1994. - Vol. 1.

[4] Krylov V.V. The theory of teletraffic and its applications. / V.V. Krylov, S.S. Samokhvalova - SPb .: BHV-Petersburg. - 2005 - 288 pp $\therefore$ il. [in Russian].

[5] Mandelbrot B. The Fractal Geometry of Nature // Computing in mathematics, physics, biolog; translate from engl. B. Mandelbrot - M.: Institute of Computer Scienc, - 2002. [in Russian].

[6] Lozhkovskyi A.G. Modeling a multi-channel service system with queue organization / A.G. Lozhkovskyi, N.S. Salmsnov, O.V. Verbanov // Eastern European Journal of Advanced Technology. 2007. - № 3/6 (27). - P. 72-76. [in Russian]. 


\section{А.Г. Ложковський, С.В. Левенберг}

Апроксимація залежності коефіціснта Херста від параметра розподілу трафіка

Проблематика. Незважаючи на популярність моделі самоподібного трафіка, до сих пір ряд задач оцінки якості обслуговування в пакетній мережі зв’язку $€$ невирішеними. Через відсутність строгої теоретичної бази, здатної доповнити класичну теорію масового обслуговування при проектуванні пакетної мережі зв'язку 3 самоподібним трафіком, не існує достовірної і визнаної методики розрахунку параметрів і показників якості систем розподілу інформації в умовах ефекту самоподоби.

Мета досліджень. Підвищення точності розрахунку характеристик якості обслуговування шляхом отримання нової формули розрахунку коефіцієнта самоподібності трафіка в залежності від параметра форми розподілу Вейбулла або Парето, оскільки самоподібний трафік (інтервал часу між пакетами потоку) описується цими розподілами.

Методика реалізації. Для розрахунку характеристик QoS необхідно знати лише параметр $a$ форми розподілу Вейбулла або Парето і нема необхідності розраховувати достатньо складним способом, наприклад, методом $R / S$ статистики, коефіцієнт самоподібності Херста для трафіка.

Результати досліджень. Виявлено суттєву відмінність реальної і використаної тепер лінійної залежності коефіцієнта самоподібності $H$ від параметру $a$ форми розподілу Вейбулла або від параметру $а$ форми розподілу Парето.

Висновки. Використання реальних функціональних залежностей $H$ від $a$ дозволяє підвищити точність розрахунку характеристик якості обслуговування на порядок.

Ключові слова: якість обслуговування, коефіцієнт Херста, самоподібний трафік.

\section{А.Г. Ложковский, С.В. Левенберг}

\section{Аппроксимация зависимости коэффициента Херста от параметра распределения трафика}

Проблематика. Несмотря на популярность модели самоподобного трафика, до сих пор ряд задач оценки качества обслуживания в пакетной сети связи остается нерешенными. Из-за отсутствия строгой теоретической базы, способной дополнить классическую теорию массового обслуживания при проектировании пакетной сети с самоподобным трафиком, не существует достоверной и признанной методики расчета параметров и показателей качества систем распределения информации в условиях эффекта самоподобия.

Цель исследований. Повышение точности расчета характеристик качества обслуживания путем получения новой формулы расчета коэффициента самоподобности трафика в зависимости от параметра формы распределений Вейбулла или Парето, т.к. самоподобный трафик (интервал времени между пакетами потока) описывается этими распределениями.

Методика реализации. Для расчета характеристик QoS необходимо знать лишь параметр а формы распределения Вейбулла или Парето и нет необходимости рассчитывать достаточно сложным способом, например, методом $R / S-$ статистики, коэффициент самоподобности Херста для трафика.

Результаты исследований. Обнаружено существенное отличие реальной и используемой сейчас линейной зависимости коэффициента самоподобности $H$ от параметра $a$ формы распределения Вейбулла или от параметра $a$ формы распределения Парето.

Выводы. Использование реальных функциональных зависимостей $H$ от $a$ позволяет повысить точность расчета характеристик качества обслуживания на порядок.

Ключевые слова: качество обслуживания, коэффициент Херста, самоподобный трафик. 